\title{
Ly6/PLAUR Domain-Containing Protein 3
}

National Cancer Institute

\section{Source}

National Cancer Institute. Ly6/PLAUR Domain-Containing Protein 3. NCI Thesaurus. Code C132242.

Ly6/PLAUR domain-containing protein 3 (346 aa, $36 \mathrm{kDa}$ ) is encoded by the human LYPD3 gene. This protein is involved in cell-matrix interactions during cell migration. 